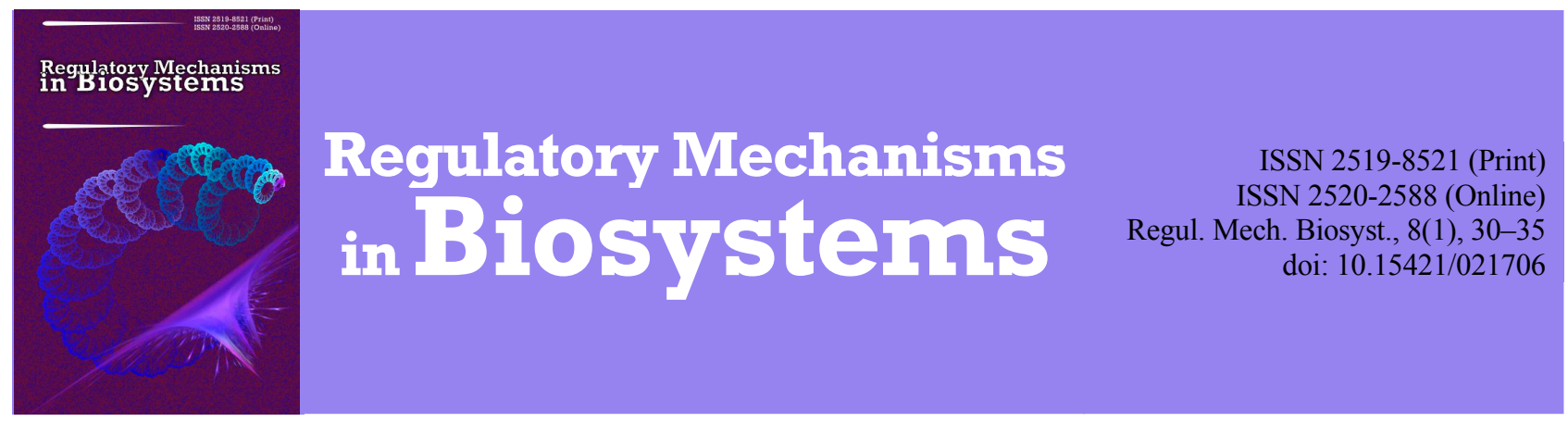

\title{
Effect of 3-arylamino-1,2-dihydro-3H-1,4-benzodiazepine-2-ones on the bradykinin-induced smooth muscle contraction
}

\author{
P. A. Virych*, O. V. Shelyuk*, T. A. Kabanova**, O. I. Khalimova**, \\ V. S. Martynyuk*, V. I. Pavlovsky**, S. A. Andronati** \\ *Taras Shevchenko National University of Kyiv, Kyiv, Ukraine \\ **O. V. Bogatsky Physico-Chemical Institute, National Academy of Sciences of Ukraine, Odesa, Ukraine
}

Article info

Received 28.12.2016

Received in revised form 26.01.2017

Accepted 28.01.2017

Taras Shevchenko

National University of Kyiv,

Glushkova Str., 2

Kyiv, 03022, Ukraine

Tel: $+38-096-702-80-44$

E-mail: sphaenodon@ukr.net

O. V. Bogatsky

Physico-Chemical Institute, National Academy of Sciences of Ukraine, Lustdorfska Doroga 86, Odesa 65080, Ukraine Tel: $+38-097-905-92-97$ E-mail:

victorpavlovsky@ukr.net
Virych, P. A., Shelyuk, O. V., Kabanova, T. A., Khalimova, O. I., Martynyuk, V. S., Pavlovsky, V. I., \& Andronati, S. A. (2017). Effect of 3-arylamino-1,2-dihydro-3H-1,4-benzodiazepine-2-ones on the bradykinin-induced smooth muscle contraction. Regulatory Mechanisms in Biosystems, 8(1), 30-35. doi: 10.15421/021706

Damage to tissue, inflammation and disruption of normal functioning of organs are often accompanied by pain. In pain perceptions, the kinin-kallikrein system with bradykinin as mediator is very important. Regulatory activity of the kininkallikrein system permits the control of inflammation, pain, vascular tone and other functions. A new group of substances that may used for this purpose are 3-substituted 1,4-benzdiazepinones. We analyzed the effect of 3-arylamino-1,2-dihydro$3 \mathrm{H}-1,4$-benzodiazepine-2-ones derivatives on the normalized maximal rate of bradykinin-induced smooth muscle contraction of the stomach in the presence of calcium channel blockers verapamil $(1 \mu \mathrm{M})$ and gadolinium $(300 \mu \mathrm{M})$. The levels of bradykinin and 3-arylamino-1,2-dihydro-3H-1,4-benzodiazepine-2-ones in the incubation solution were $10^{-6} \mathrm{M}$. Data processing on the dynamics of contraction was performed according to the method of T. Burdyha and S. Kosterin. Statistically significant changes were found for MX-1828. This compound reduced the maximal normalized rate of bradykinin-induced smooth muscle contraction in the presence of $\mathrm{Gd}^{3+}$ and verapamil by $19.3 \%$ and $32.0 \%$, respectively. Also, MX-1828 demonstrated effects similar to those of the competitive inhibitor bradykinin $\mathrm{B}_{2}$-receptor - des-Arg9bradykinin-acetate, which is possible evidence of its interaction with the receptor or signal transduction pathways. MX-1828 additionally reduced the maximum normalized rate of relaxation by $6.2 \%$ in the presence of $\mathrm{Gd}^{3+}$. This effect was demonstrated for MX-1906 in the presence of verapamil with additional reduction of the maximal normalized rate of relaxation, which was $26.4 \%$. The results suggest the presence of inhibitory interaction between MX-1828 and kininkallikrein system receptors or signal transduction pathways. The effects which were found for MX-1906 require further studies to clarify the mechanisms of influence on bradykinin-induced smooth muscle contraction.

Keywords: 3-substituted 1,4-benzodiazepines; bradykinin; kinin-kallikrein system; maximal normalized rate

\section{Вплив 3-ариламіно-1,2-дигідро-3Н-1,4-бенздіазепін-2-онів на брадикінін-індуковане скорочення гладеньких м'язів}

\author{
П. А. Вірич*, О. В. Шелюк*, Т. А. Кабанова**, О. І. Халімова**, \\ В. С. Мартинюк*, В. І. Павловський**, С. А. Андронаті**
}

*Київський наиіональний університет імені Тараса Шевченка, Київ, Украӥна **Фізико-хімічний інститут імені О. В. Богатського НАН Украйни, Одеса, Украӥна

Особливості біологічної дії похідних бенздіазепінонів визначаються їх хімічною структурою та взаємодією з біохімічними мішенями. Проаналізовано вплив 3-ариламіно-1,2-дигідро-3Н-1,4-бенздіазепін-2-онів на зміни максимальної нормованої швидкості брадикінініндукованого скорочення гладеньких м'язів за присутності іонів гадолінію та верапамілу. Статистично достовірні зміни виявлено для МX1828 , яка здатна додатково інгібувати брадикінін-індуковане скорочення за присутності $\mathrm{Gd}^{3+}$ на $19,3 \%$ та на $32,0 \%$ за присутності верапамілу, а також демонструє ефекти, подібні до тих, що виявляє конкурентний інігібітор В bradykinin-acetate, що свідчить про іï взаємодії з рецептором або шляхами трансдукції сигналу. Максимально нормована швидкість розслаблення додатково знижується на 6,2\% при додаванні MX-1828 за присутності $\mathrm{Gd}^{3+}$. Також за присутності верапамілу такий ефект характерний для MX-1906 і складає 26,4\%. Отримані дані дозволяють висунути припущення про взаємодію MX-1828 з В кінін-калікреїнової системи за механізмом інгібування. Додаткових досліджень потребує сполука МХ-1906, що виявляє такий ефект за присутності в інкубаційному розчині верапамілу.

Ключові слова: 3-заміщені 1,4-бенздазепін-2-они; брадикінін; кінін-калікреїнова система; максимальна нормована швидкість 


\section{Вступ}

Біль - складне багатовимірне сенсорно-прецептивне явище. Відчуття болю виникає в результаті порушення цілісності організму або його нормального функціонування за дії зовнішніх чи внутрішніх факторів. Особливої уваги заслуговує хронічний біль, що створює особливу нішу фінансових витрат. Наразі розрізняють два типи хронічного болю: ноцицептивний і нейропатичний. Під першим поняттям розуміють біль, який виникає у відповідь на пошкодження нервової тканини, що пов'язано 3 активацією ноцицепторів нормально функціонуючої соматосенсорної системи (Baron et al., 2010). Нині icнує декілька механізмів нейропатичного болю, що описуються моделями Бенета - Kci (Bennett - Xie), Шіна та Чанга (Sheen and Chung), Кіма та Чанга (Kim and Chung) і Зельцера (Seltzer) (Kerstman et al., 2013). За пошкодження нервових волокон виникає спонтанна електронна збудливість і надчутливість, що проявляється зміною експресії медіаторів, нейромодуляторів, факторів росту, рецепторів і нейроактивних молекул первинних аферентних нейронів. Така периферична сенсибілізація посилює ноцицепцію, що викликає больову гіперчутливість, у тому числі до виникнення спонтанного болю та гіперальгезивного підвищення температури. Крім того, продукція та вивільнення запальних медіаторів і прозапальних цитокінів може викликати больову гіперчутливість (Watkins and Maier, 2002; Ludwig and Baron, 2004; Gierthmuhlen et al., 2014).

Залежно від типу больового відчуття застосовують анестетики загальної або місцевої дії. Найімовірніші кандидати на роль мішеней для анестетиків загальної дії - ліганд-керовані іонні канали. В цілому відбувається блокування або порушення рецептор-лігандних взаємодій таких каналів як GABAA. Також для деяких речовин, наприклад кетаміну, характерне блокування NMDA рецепторів (N-метил-d-аспартат, тип глутаматних рецепторів) (Pleuvry, 2008; Garcia et al., 2010).

Місцеві анестетики почали використовувати понад 100 років тому. Їх взаємодія з натрієвими каналами викликає бажанй ефект. Проте вони здатні модифікувати активність калієвих і кальцієвих каналів, а також перебіг внутрішньоклітинних процесів (Scholz, 2002). Застосування високих доз місцевих анестетиків може спричинити судоми. Крім того більшість таких речовин впливає на тонус судин, що сприяє розвитку гіпотонії (Becker and Reed, 2006).

Кінін-калікреїнова ситема може виступати однією з ланок больової чутливості, а також виконувати в організмі низку інших функцій: регуляція тиску крові, участь у запальних процесах, серцево-судинному гомеостазі, знеболювальних відповідях, больовій передачі, клітинній проліферації, вивільненні цитокінів, простацикліну, оксиду азоту (NO), регуляції функцій гладеньких м'язів судин, шлунково-кишкового тракту тощо (Pesquero and Bader, 1998).

Дія кінінів у тканинах і кровоносних судинах жорстко контролюється завдяки процесам їх утворення та деградації. У плазмі фактор згортання крові XII (фактор Хагеманна) активується негативно зарядженими поверхнями з утворенням форми ХIIa, яка, у свою чергу, здатна розщеплювати прекалікреїнові похідні в активні калікреїни. Останні, завдяки гідролітичній активності, вивільняють із високомолекулярних кініногенів брадикінін (БК), що надходить у кров'яне русло. Клітинна відповідь на дію цього пептиду опосередковується активацією брадикінінових рецепторів двох підтипів - $\mathrm{B}_{1}$ та $\mathrm{B}_{2}$, що належать до родини рецепторів, спряжених із G-білками, та опосередковують свою дію через Gq білки. Після видалення С-кінцевого залишку аргініну кініназами БК перетворюється на des-Arg9-BK інший високоактивний пептид. БК високоспоріднений до конститутивних кінінових рецепторів $\mathrm{B}_{2}\left(\mathrm{~B}_{2} \mathrm{R}\right)$, у той час як desArg9-BK - до індуктивних кінінових рецепторів $\mathrm{B}_{1}\left(\mathrm{~B}_{1} \mathrm{R}\right)(\mathrm{Al}-$ bert-Weibenberger et al., 2013). Це, у свою чергу, супроводжується синтезом вторинних посередників - інозитол-1,4,5-трифосфату та діацилгліцеролу. В експресія тканинноспецифічно посилюється запальними цито- кінами, зокрема, інтерлейкіном-1 і факторами некрозу пухлин $\alpha$ та $\beta$. B $_{1}$-рецептори експресуються в умовах розвитку травми та запалення. У гладеньких м'язах дихальних шляхів, шлунково-кишкового тракту та міометрію активація рецепторів БК спричиняє скорочення. На противагу цьому, переважною реакцією гладеньких м'язів судин на аплікування БК є розслаблення, внаслідок чого підвищується проникність судинної стінки та розвивається набряк навколишніх тканин; як наслідок, спостерігається фосфоліпаза А -опосередковане вивільнення простагландинів і лейкотрієнів (Higashida et al., 1986). Як правило, такі клітинні відповіді на дію БК опосередковані $\mathrm{Ca}^{2+}$-залежними механізмами внутрішньоклітинного сигналінгу.

За останнє десятиліття розроблено низку високоафінних $\mathrm{B}_{2}$-антагоністів 3 функціональною активністю in vivo. Серед них варто відмітити FR 173675 (Fujisawa Pharmaceutical) один із перших перорально доступних, наномолярних високоселективних інгібіторів $\mathrm{B}_{2}$-рецепторів людини. Активний $\mathrm{i}$ селективний $\mathrm{B}_{2}$ антагоніст LF 16-0687 (Fournier), який можна використовувати як водорозчинну димезилатну соль для парентерального уведення та володіє високою афінністю до брадикінінових $\mathrm{B}_{2}$-рецепторів людини, щурів та морської свинки. Варто відмітити нещодавно створений антагоніст MEN 16132 (Menarini Richerche), який має конформаційно обмежену структуру 4-аміно-4-карбокситетрагідропірану та заряджену $\mathrm{N}-\delta$-триметил-орнітинову частину, який тривало та повністю інгібував ініційований брадикініном бронхоспазм і назальне запалення за місцевого застосування. За останні роки підвищився інтерес до інгібіторів $\mathrm{B}_{1}$-рецепторів, серед яких найвідоміші SSR 240612 (Sanofi-Synthelado Recherche), LF 22-0542 (Fournier), NVP SAA 164 (Novartis). Часто для синтезу пептидоміметиків використовують 1,4-бензидіазипінове ядро, здатне імітувати $\beta$-вигин, що має важливе значення для біологічно активних форм пептидів. Цей клас речовин володіє високою біодоступністю та добре переноситься пацієнтами. Структурний елемент $\beta$-вигину, встановлений для біоактивної конформації НОЕ 140, став основою для дизайну непептидних $\mathrm{B}_{2}$-антагоністів, що мають бенздіазепіновий каркас (Dziadulewicz et al., 1999). На основі цих досліджень синтезовано антагоніст $\mathrm{B}_{1}$-рецепторів людини (Andronati et al., 2009).

Науковий колектив Фізико-хімічного інституту НАН України ім. О. В. Богатського запропонував новий клас перспективних сполук на основі 3-заміщених 1,4-бенздіазепінів, які демонструють анальгетичний ефект i, ймовірно, інгібують БК рецептори. Експериментальні дані демонструють здатність деяких похідних бенздіазепінів проявляти чітку антигіперальгезивну активність відносно запального та невропатичного болю в моделях на тваринах. Деякі похідні бенздіазепінів можуть викликати глибоку анальгезію у тварин (Andronati et al., 2009). Подальша селекція перспективних сполук потребує всебічного оцінювання їх біологічної активності та ретельного дослідження молекулярних та системних механізмів дії.

Виходячи 3 вищенаведеного, слід зазначити, що модель брадикінін-індукованого скорочення гладеньких м'язів шлунку проста та інформативна для з'ясування механізмів впливу 3-заміщених 1,4-бенздіазепінонів на рецепторний апарат кінінкалікреїнової системи. Присутність інгібіторів різних ланок трансдукції сигналу від конститутивно присутніх $\mathrm{B}_{2}$-рецепторів дозволить краще зрозуміти особливості взаємодії обраних сполук із мішенями їх дії. Тому мета цього дослідження - 3'ясувати механізми впливу 3-ариламіно-1,2-дигідро-3Н-1,4-бенздіазепін-2-онів на брадикінін-індуковане скорочення гладеньких м'язів за присутності інгібіторів кальцієвих каналів - верапамілу та $\mathrm{Gd}^{3+}$.

\section{Матеріал та методи досліджень}

Скоротливу активність гладеньких м'язів досліджено в ізометричному режимі. Для цього самців щурів масою 240-260 г декапітували, вилучали шлунок і поміщали в розчин Кребса. 
Усі маніпуляції з тваринами проводили згідно з Міжнародною конвенцією роботи 3 тваринами та Законом України «Про захист тварин від жорстокого поводження». Смужки розміром 1,5-2,0 x 10 мм вирізали з антральної частини шлунка, видаляли серозну та слизову оболонки, розміщували в робочій камері 3 проточним розчином Кребса (1,5 мл/хв), термостатованій за $37^{\circ} \mathrm{C}$. Препарат перебував під пасивним натягом силою $10 \mathrm{MH}$ та інкубували 1 год до появи спонтанної активності або сталих механокінетичних параметрів скорочення у відповідь на стимуляцію гіперкалієвим розчином. Реєстрацію сигналів проводили за допомогою модуля збору даних m-DAQ12 (Holit Data Systems Ltd., Україна) та програмного забезпечення Power Graph Professional 3.3. У дослідженнях використовували розчин Кребса (мM): $120,4 \mathrm{NaCl}, 5,9 \mathrm{KCl}, 15,5 \mathrm{NaHCO}_{3}, 1,2 \mathrm{NaH}_{3} \mathrm{PO}_{4}, 1,2$ $\mathrm{MgCl}_{2}, 2,5 \mathrm{CaCl}_{2}, 11,5$ глюкоза, $\mathrm{pH}$ розчину становив 7,4. Гіперкалієвий розчин (концентрація $\mathrm{K}^{+} 80 \mathrm{MM}$ ) готували шляхом ізотонічної заміни у вихідному розчині Кребса необхідної частини $\mathrm{Na}^{+}$на еквімолярну кількість іонів калію. Робочу концентрацію брадикініну в інкубаційному розчині $\left(10^{-6} \mathrm{M}\right)$ одержували шляхом внесення аліквоти маточного розчину в інкубаційну камеру. Для додаткового оцінювання біологічних ефектів 3-ариламіно-1,2-дигідро-3Н-1,4-бенздіазепін-2-онів використовували спектр концентрацій брадикініну $10^{-10}-10^{-6} \mathrm{M}$ та конкурентний інгібітор $\mathrm{B}_{2} \mathrm{R}$ des-Arg9-bradykinin-acetate в концентрації $10^{-6} \mathrm{M}$.

Бенздіазепіни попередньо розчиняли в диметилсульфоксиді (ДМСО) та вносили в розчин Кребса (остаточно вміст органічного розчинника складав $1 \%$ загального об'єму розчину). Дію досліджуваних речовин вивчали за однаковим протоколом експерименту, сполуки вносили в розчин Кребса за 30 хв до реєстрації механічної активності препаратів. Кінцева концентрація похідних 3-заміщених 1,4-бенздіазепінонів в інкубаційному середовищі складала $10^{-6} \mathrm{M}$. Перелік використаних речовин та їх хімічну структуру наведено в таблиці 1 .

Відповідний блокатор присутній в омивальному розчині Кребса. Концентрація $\mathrm{Gd}^{3+}$ становила 300 мкМ, верапамілу 1 мкМ. Як контрольні зразки використовували смужки гладеньких м'язів шлунка щурів, до інкубаційного середовища яких додавали аліквоту диметилсульфоксиду (ДМСО), яка не перевищувала $1 \%$ загального об'єму. Це пов'язано з тим, що похідні 3-заміщених 1,4-бенздіазепінонів гідрофобні, але добре розчиняються у ДМСО. Тому для адекватного порівняння ефектів похідних 3-заміщених 1,4-бенздіазепінонів до контрольних зразків також додавали еквівалентну кількість ДМСО. Повторність досліду десятиразова.

Вивчення механокінетики процесу скорочення м'язових препаратів здійснювали відповідно до методу Burdyga and Kosterin (1991). Перевага даного аналізу - незалежність від амплітуди скоротливих відповідей. Це дає можливість коректно порівнювати дані, одержані на м'язових препаратах різного розміру. Ефект 3-заміщених 1,4-бенздіазепін-2-онів оцінювали шляхом вирахування різниці між контрольними брадикінін-індукованими скороченнями та за присутності відповідних речовин.

Статистичну обробку результатів здійснювали загальноприйнятими методами варіаційної статистики за допомогою пакетів програм Statistica 8.0 та Origin Lab 8.0. Отримані результати перевіряли на нормальність розподілу тестом Шапіро Вілка. Якщо дані не відповідали закону нормального розподілу, порівняння незалежних вибірок здійснювали за критерієм Краскела - Уолліса. За нормального розподілу, порівняння різниці між контрольними та дослідними вимірами проводили за допомогою ANOVA (Шеффе-тест) для незалежних вибірок. Рівень значущості становив $\mathrm{P}<0,05$.

\section{Результати}

У цьому дослідженні проаналізовано вплив 3-ариламіно1,2-дигідро-3Н-1,4-бенздіазепін-2-онів на брадикінін-індуковане скорочення гладеньких м'язів у діапазоні концентрацій агоніста $10^{-10}-10^{-6}$ М. Як зразок порівняння використали конкурентний інгібітор $\mathrm{B}_{2} \mathrm{R}$ des-Arg9-bradykinin-acetate. Головною кінетичною характеристикою скорочення, згідно із застосованим методом обрахунку стала максимальна нормована швидкість (Vn). За концентрації БК $10^{-6}$ М відбувається статистично достовірне зростання даного показника на $20,5 \%$. Подібний ефект характерний для сполуки MX-1828. За низьких концентрацій брадикініну $10^{-10}, 10^{-9} \mathrm{M}$ відбувається інгібування $\mathrm{Vn}$ на $20,7 \%$ та 8,6\% відносно контрольних скорочень. За $10^{-6}$ М БК зареєстровано зворотний ефект - зростання на 10,7\%. Ці зміни подібні до дії des-Arg9-bradykinin-acetate, що свідчать про можливі взаємодії речовини з рецепторним апаратом кінін-калікреїнової системи або шляхами трансдукції (рис. 1).

\section{Таблиця 1}

Хімічна структура

3-ариламіно-1,2-дигідро-3Н-1,4-бенздіазепін-2-онів

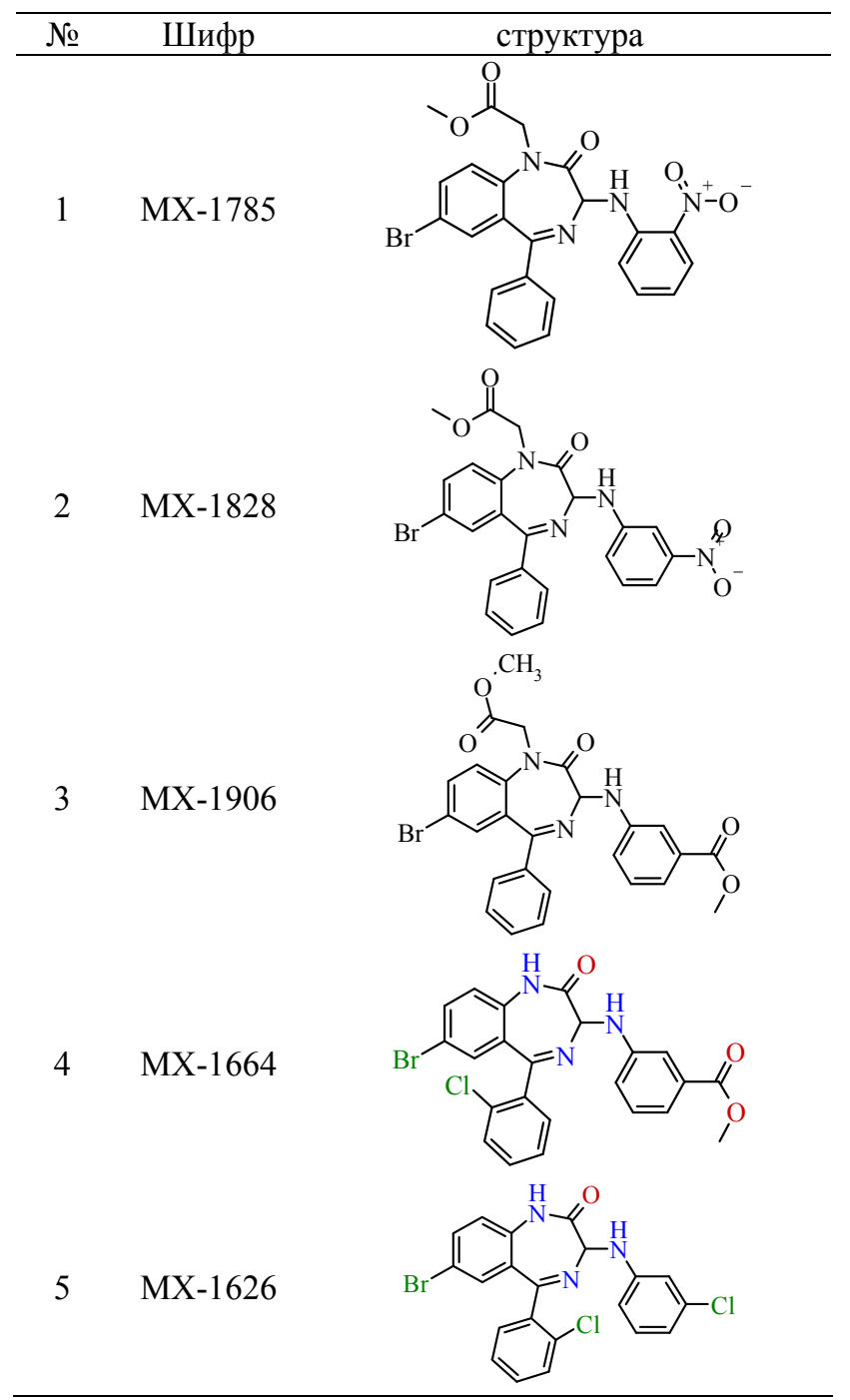

Інші сполуки демонструють ефекти інгібування, які практично не залежать від концентрації брадикініну. Так, MX-1785 здатна знижувати Vn брадикінін-індукованого скорочення на $10-13 \%$ для діапазону концентрацій агоніста $10^{-10}-10^{-7} \mathrm{M}$. Лише за $10^{-6}$ М БК статистично достовірної різниці не виявлено (рис. 1). Для МХ-1906 та МХ-1626 спостерігається характерне зниження Vn скорочення на 28-22\% у діапазоні концентрацій брадикініну $10^{-9}-10^{-6} \mathrm{M}$. За $10^{-10} \mathrm{M} \mathrm{БК} \mathrm{статистично} \mathrm{достовірну}$ різницю не виявлено для MX-1906. MX-1664 знижує Vn на $25 \%$ за індукції скорочення $10^{-8}-10^{-6}$ М БК. Дещо менший ефект $12-14 \%$ характерний для концентрацій $10^{-10}-10^{-9}$ М БК (рис. 2). Отже, серед спектра 3-ариламіно-1,2-дигідро-3Н-1,4бенздіазепін-2-онів варто виділити сполуку МX-1828, яка 
демонструє ефекти, подібні до конкурентного інігібітора $\mathrm{B}_{2}$ рецепторів брадикініну, що $\epsilon$ можливим свідченням іiі дії на рецептор або на його шляхи трансдукції сигналу.

Механокінетичні параметри скоротливої активності гладеньких м'язів за присутності $\mathbf{G d}^{3+}$. Процеси скорочення гладеньких м'язів запускаються зростаючим рівнем цитозольного кальцію, який, зв'язуючись зі специфічними протеїнами, індукує процеси взаємодії актину з міозином. Зростання забезпечується ліганд- і потенціал-керованими кальцієвими каналами мембрани та саркоплазматичного ретикулуму. Цей струм можна регулювати, використовуючи селективні та неселектив- ні інгібітори. Для цього використовують інші, схожі за властивостями іони, які можуть взаємодіяти із селективним фільтром каналу або його алостеричним центром, змінюючи тим самим його пропускну здатність. Такими можуть бути рідкісноземельні метали, до яких належить гадоліній. Присутність іонів цього металу в розчині забезпечує зменшення кальцієвого струму через мембрану та зміну механокінетичних характеристик брадикінін-індукованого гладеньком'язового скорочення. Таким чином, максимальна нормована швидкість (Vn) брадикінін-індукованого скорочення за присутності $\mathrm{Gd}^{3+}$ знижується на 23,1\%, що обрано як контрольне значення (рис. 3).

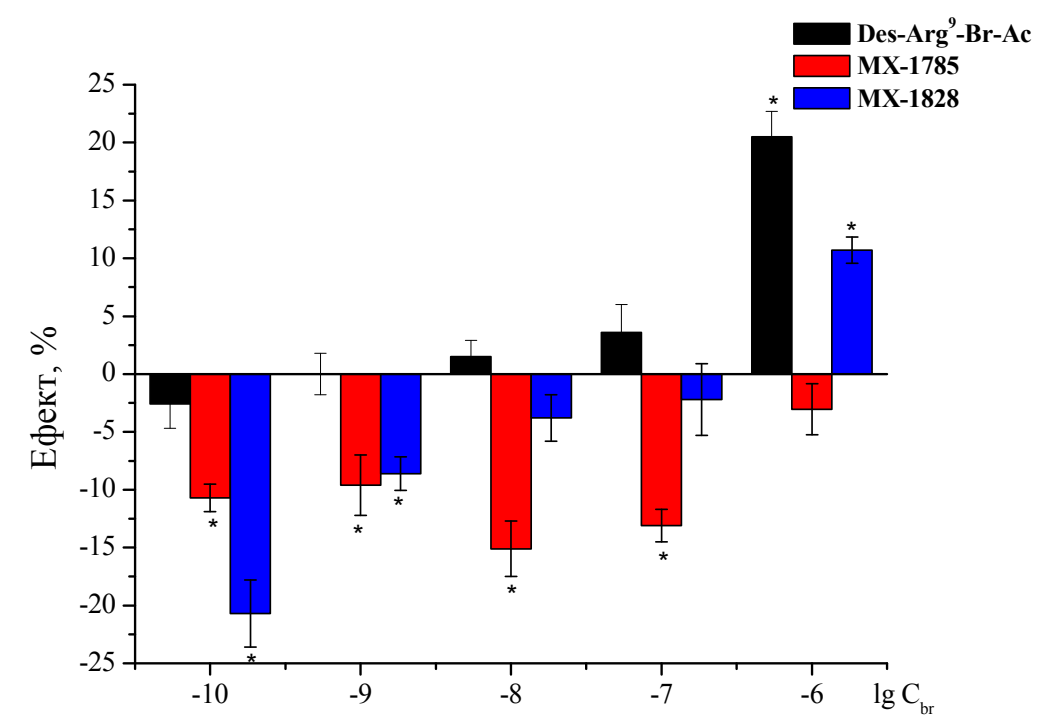

Рис. 1. Вплив 3-заміщених 1,4-бенздіазепін-2-онів на максимальну нормовану швидкість скорочення (Vn) гладеньких м'язів шлунка щурів $(\mathrm{M} \pm \mathrm{m}, \mathrm{n}=10): *-\mathrm{P}<0,05$

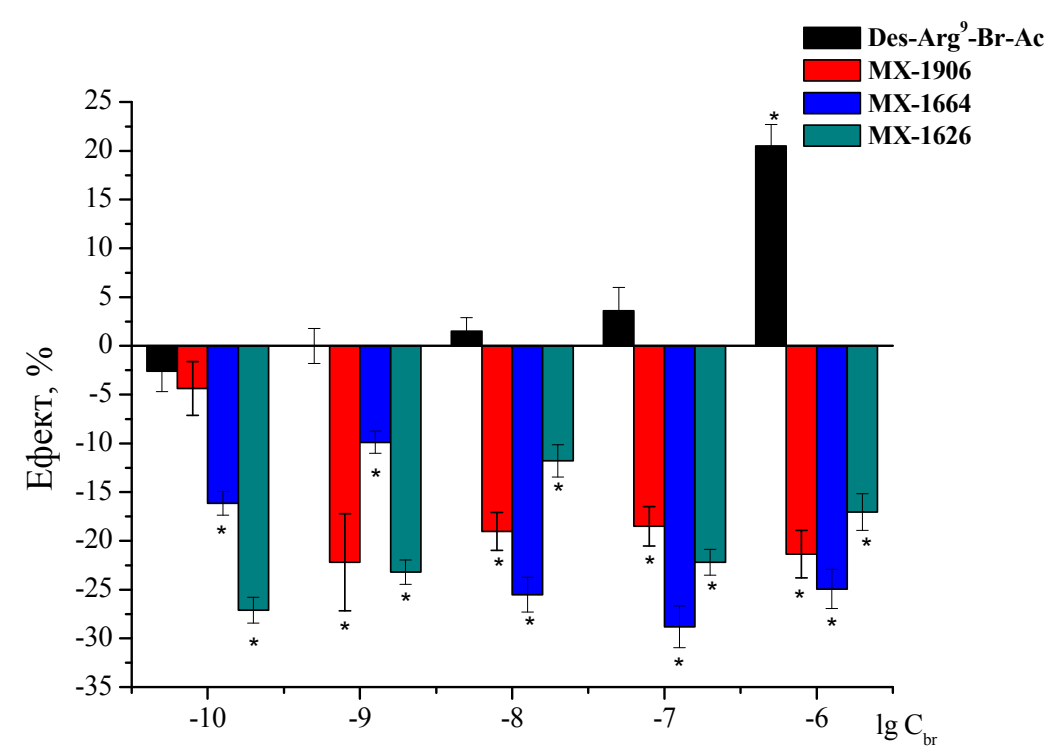

Рис. 2. Вплив 3-заміщених 1,4-бенздіазепін-2-онів на максимальну нормовану швидкість скорочення (Vn) гладеньких м'язів шлунка щурів $(\mathrm{M} \pm \mathrm{m}, \mathrm{n}=10): *-\mathrm{P}<0,05$

Присутність у розчині сполук МХ-1785, МХ-1906, МX1664 та МX-1626 не змінювала цей показник за даних умов. Для MX-1828 характерне достовірне зниження Vn порівняно 3 контрольними значеннями на 19,3\% (рис. 3).

$\mathrm{Vn}$ розслаблення за присутності $\mathrm{Gd}^{3+}$ зростає на 7,1\%, що вибрано як контрольне значення. Додавання до розчину МХ1664 сприяє зростанню Vn на 35,8\%, MX-1626 - 8,9\%. Додавання МХ-1906 забезпечує зниження цього показника відносно контролю на $37 \%$, а за відсутності $\mathrm{Gd}^{3+}$ - на $29,9 \%$ (рис. 3 ).
Результатом такого ефекту можуть служити наявні додаткові мішені впливу сполуки. Для речовини МХ-1828 також характерне незначне зниження показника максимальної нормованої швидкості розслаблення на $6,2 \%$. Статистично достовірні зміни відсутні для МХ-1785 (рис. 4).

Механокінетичні параметри скоротливої активності гладеньких м'язів за присутності верапамілу. Верапаміл класичний блокатор T- та L-типів кальцієвих каналів, які залучені в сигнальних шляхах ініціації скорочення гладеньких м'я- 
зів, у тому числі брадикінін-індукованого. Його присутність в інкубаційному розчині в концентрації 1 мкМ знижує максимальну нормовану швидкість скорочення на 49,3\%, тобто майже вдвічі. За присутності 3-заміщених 1,4-бенздіазепін-2-онів MX-1785, MX-1664, MX-1626 Vn не піддається статистично достовірним змінам (рис. 5).

Статистично достовірні відмінності Vn скорочення виявлено для MX-1828, що становлять 32\% від брадикінін-індукованих скорочень за присутності верапамілу, а також МХ-1906 3 показником додаткового інгібування 26,4\% (рис. 5).

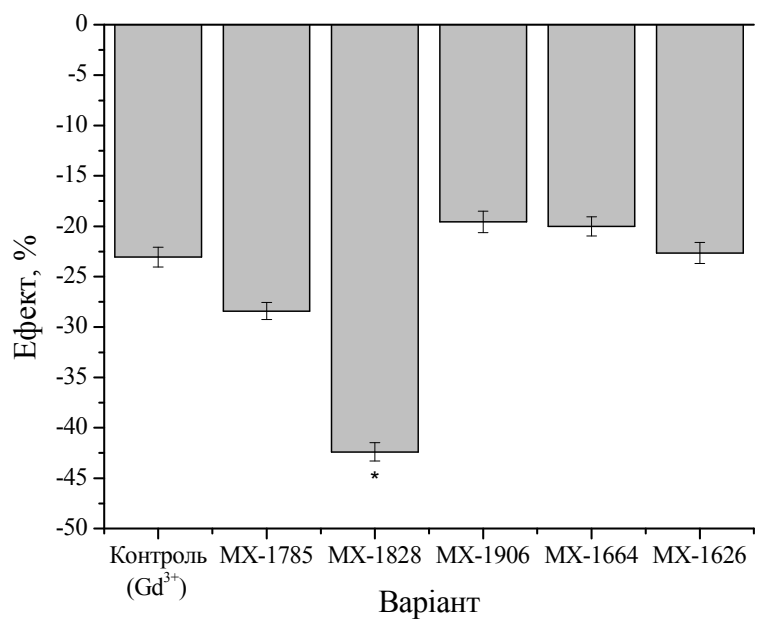

Рис. 3. Вплив 3-заміщених 1,4-бенздіазепін-2-онів на максимальну нормовану швидкість скорочення за присутності $\mathrm{Gd}^{3+}(300$ мкM): «0»- Vn брадикінініндукованого скорочення, контроль - за присутності $\mathrm{Gd}^{3+}$; $\mathrm{M} \pm \mathrm{m}, \mathrm{n}=10{ }^{*}-\mathrm{P}<0,05$

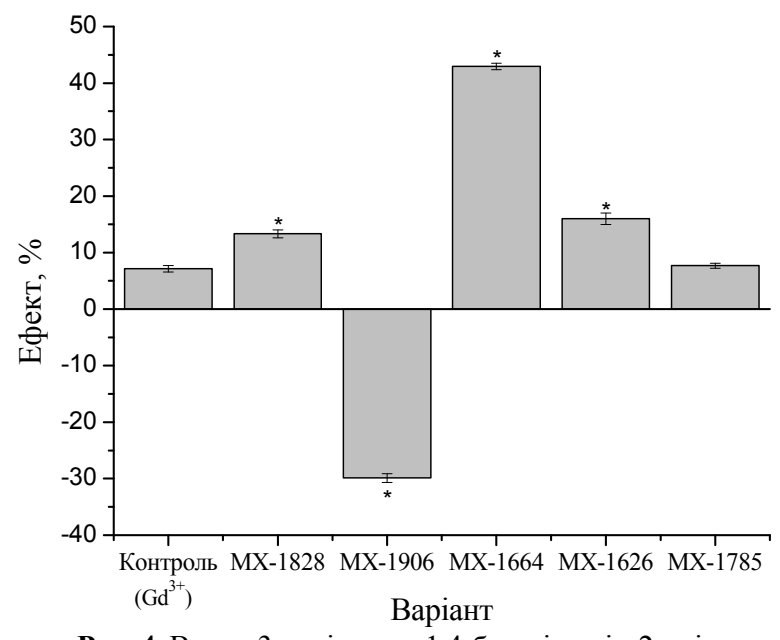

Рис. 4. Вплив 3-заміщених 1,4-бенздіазепін-2-онів на максимальну нормовану швидкість розслаблення за присутності $\mathrm{Gd}^{3+}$ (300 мкM): позначення див. рис. 3

Максимальна нормована швидкість розслаблення за присутності верапамілу зростає на $19,5 \%$ (рис. 6). Присутність в інкубаційному розчині 3-заміщених 1,4-бенздіазепін-2-онів забезпечує нівелювання такої різниці та відповідність параметра значенням брадикінін-індукованого скорочення за відсутності інгібіторів. Причому повна відсутність ефекту характерна для MX-1828, MX-1906, MX-1664 та MX-1626. Зниження швидкості на $11,6 \%$ порівняно з контрольними значеннями характерне для МХ-1785 (рис. 6).

\section{Обговорення}

Природні речовини деяких рослин після незначної хімічної модифікації структури стають перспективними модифікатора- ми активності кінін-калікреїнової системи, що доведено експериментально на скоротливій здатності шлунка мишей (Alves et al., 2015). Розвиток сучасної органічної хімії дозволяс синтезувати антагоністи непептидної природи, які потенційно можуть використовувати як блокатори активності кінін-калікреїнової системи кишечника (Kam et al., 2005). Використання блокаторів $\mathrm{B}_{2}$-рецепторів дозволяе зменшити перистальтику кишечника, у той час як інгібування $\mathrm{B}_{1}$-рецепторів сприяє зниженню запалення. Активація обох рецепорів спричиняє розвиток діареї (Stadnicki, 2011). Подібні дослідження проведено для вивчення ролі $\mathrm{B}_{1}$ та $\mathrm{B}_{2}$ кінінових рецепторів у розвитку колітів (Marcon et al., 2013).

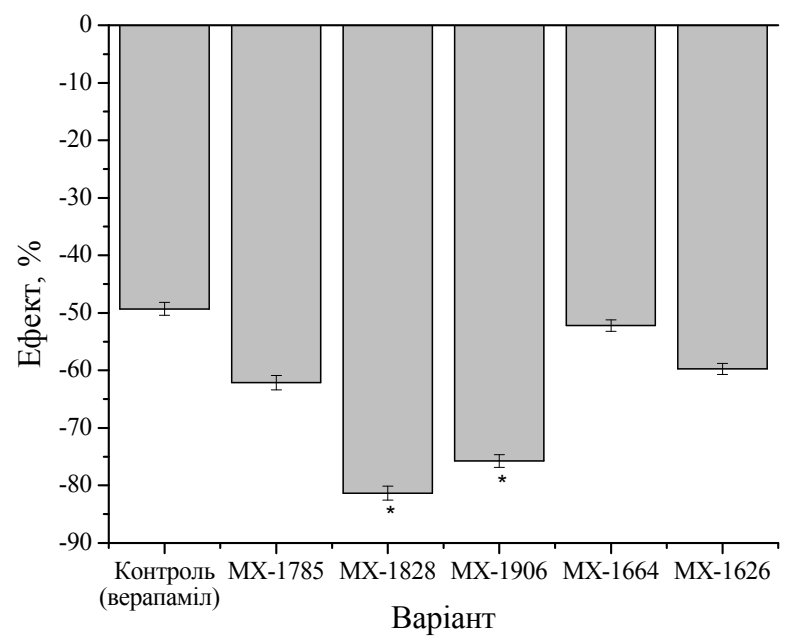

Рис. 5. Вплив 3-заміщених 1,4-бенздіазепін-2-онів на максимальну нормовану швидкість скорочення за присутності верапамілу (1 мкМ): позначення див. рис. 3

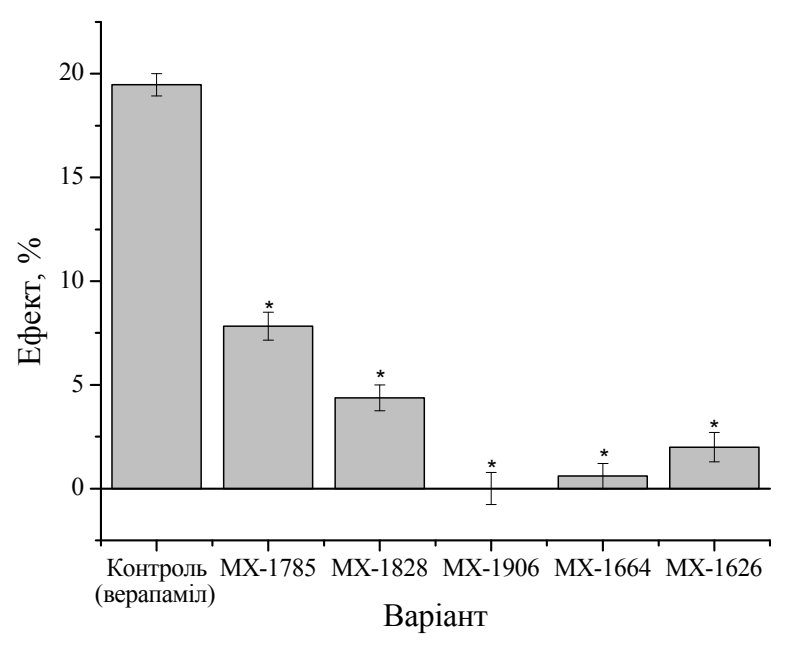

Рис. 6. Вплив 3-заміщених 1,4-бенздіазепін-2-онів

на максимальну нормовану швидкість розслаблення за присутності верапамілу (1 мкМ): позначення див. рис. 3

Похідні бенздіазепінів використовують як блокатори GABAA рецепторів. Зв'язування відбувається в алостеричному центрі рецептора, тому взаємодія може бути як інгібувальна, так і активувальна. Речовини даного класу використовують як знеболювальні агенти за нейропатичного болю, підвищеної больової чутливості, болю у м'язах тощо (Bartusch et al., 1996; Hugel et al., 2003; Chou and Huffman, 2007; Howard et al., 2014). Пошук мішеней дії похідних даного класу - важливе завдання, що дозволяє розуміти механізми, які лежать в основі отриманих ефектів. Попередньо, взаємодія досліджуваних речовин із кінін-калікреїновою системою продемонстровано дослідженнями Andronati et al. (2009) під час вивчення їх анальгетичних властивостей. Відповідно до попередніх досліджень без використання інгібіторів виявлено, що сполука MX-1828 здатна викликати ефекти, схожі до des-Arg9-bradykinin-acetate. Ми вису- 
нули припущення про можливі іiі взаємодії з рецепторним апаратом кінін-калікреїнової системи, у тому числі з $\mathrm{B}_{2}$-рецепторами. Виходячи зі структури речовин та їх гідрофобності, вони здатні не лише вбудовуватись у мембрану, а і проникати всередину клітини. Тому, крім прямої взаємодії з рецептором, можливо, існують механізми їх впливу на шляхи трансдукції сигналу, що виявляється в ефектах, які ми зареєстрували.

Використання інгібіторів різного типу дозволяє виключити окремі ланки трансдукції сигналу від брадикінінових рецепторів та виявити можливий синергізм чи антагонізм їх дії з 3-заміщеними 1,4-бенздіазепін-2-онами. Для цього використовували верапаміл та іони гадолінію $\left(\mathrm{Gd}^{3+}\right)$. Рідкісноземельні метали здатні змінювати кальцієву провідність мембрани за рахунок взаємодії із селективним фільтром каналів, зменшуючи, таким чином, інтрацелюлярний потік $\mathrm{Ca}^{2+}$ (Malasics et al., 2010), a верапаміл - класичний блокатор потенціал-активованих кальцієвих каналів L- та Т-типів (Bergson et al., 2011).

Максимальна нормована швидкість розслаблення вказує на тривалість підтримання високого рівня цитоплазматичного кальцію, що визначається часом взаємодії агоніста 3 рецептором, ефективності роботи ланцюга трансдукції, кальцієвих каналів і помп, роботи скоротливого апарату та спряжених систем. Отримані результати (рис. 1 та 2) вказують на зниження максимальної швидкості скорочення для сполук МX-1785, MX-1906, MX-1664, MX-1626 за використаного діапазону концентрацій $10^{-10}-10^{-6} \mathrm{M}$. Теоретично всі речовини виступають перспективними блокаторами брадикінін-індукованого скорочення гладеньких м'язів. Але застосування інгібіторів дозволило ідентифікувати речовину MX-1828, що попередньо відібрана завдяки ефектам, подібним до відомого блокатора $\mathrm{B}_{2}$-рецепторів. Можна припустити, що вона володіє більшим афінітетом до рецепторів порівняно 3 іншими або взаємодіє 3 початковими ланками трансдукції сигналу, тому, на фоні використаних кальцієвих блокаторів, забезпечує додаткові зміни максимальної нормованої швидкості скорочення та розслаблення гладеньких м'язів.

Використання інгібіторів кальцієвих каналів дозволило ідентифікувати речовини, здатні впливати на ланки трансдукції сигналу брадикінінових рецепторів, забезпечуючи додаткове зниження чи збільшення механокінетичних параметрів скорочення гладеньких м'язів. Отримані дані дозволяють висунути припущення про взаємодію МX-1828 із кінін-калікреїновою системою за механізмом інгібування. Разом із тим додаткових досліджень потребує сполука МX-1906, що виявляє такий ефект за присутності в інкубаційному розчині верапамілу.

\section{Висновки}

Серед спектра досліджуваних 3-ариламіно-1,2-дигідро-3Н1,4-бенздіазепін-2-онів варто виділити сполуку МХ-1828, яка демонструє ефекти, подібні до ефектів конкурентного інігібітора $\mathrm{B}_{2}$-рецепторів брадикініну - des-Arg9-bradykinin-acetate, що свідчить про ії взаємодії з рецептором або шляхами трансдукції сигналу. Ця речовина здатна додатково знижувати максимальну нормовану швидкість скорочення за присутності інгібіторів кальцієвих каналів верапамілу та іонів гадолінію на $32,0 \%$ та 19,3\%, відповідно. Також за присутності верапамілу такий ефект характерний для МХ-1906 (складає 26,4\%), що потребує додаткових досліджень у з'ясуванні мішеней впливу сполуки на брадикінін-індуковане скорочення.

Дослідження проведені за підтримки Державного фонду фундаментальних досліджень за договорами Ф64/19-2015 та Ф64/40-2016.

\section{References}

Albert-Weibenberger, C., Siren, A., \& Kleinschnitz, C. (2013). Ischemic stroke and traumatic brain injury: The role of the kallikrein-kinin system. Progress in Neurobiology, 101-102, 65-82.
Altamura, M., Meini, S., Quartara, L., \& Maggi, C. (1999). Nonpeptide antagonists for kinin receptors. Regulatory Peptides, 80, 13-26.

Alves, F., Oliva, M., \& Miranda, A. (2015). Conformational and biological properties of Bauhinia bauhinioides kallikrein inhibitor fragments with bradykinin-like activities. Journals of Peptide Science, 21, 495-500.

Andronati, S., Kabanova, T., Pavlovskij, V., Andronati, K., \& Bachins'kij, S. (2009). Ligandy bradikininovyh receptorov kak potencial'nie anal'geticheskie i protivovospalitel'nie sredstva. Zhurnal Organichnoji ta Farmacevtichnoji Khimiji, 28(4), 70-76 (in Russian).

Baron, R., Binder, A., \& Wasner, G. (2010). Neuropathic pain: Diagnosis, pathophysiological mechanisms, and treatment. The Lancet Neurology, 9(8), 807-819.

Bartusch, S., Sanders, B., D’Alessio, J., \& Jernigan, J. (1996). Clonazepam for the treatment of lancinating phantom limb pain. The Clinical Journal of Pain, 12, 59-62.

Becker, D., \& Reed, K. (2006). Essentials of local anesthetic pharmacology. Anesthesia Progress, 93(3), 98-109.

Bergson, P., Lipkind, G., Lee, S., Duban, M., \& Hanck, D. (2011). Verapamil block of T-type calcium channels. Molecular Pharmacology, 79(3), 411-419.

Burdyga, T., \& Kosterin, S. (1991). Kinetic analysis of smooth muscle relaxation. General Physiology and Biophysics, 10, 589-598.

Chou, R., \& Huffman, L. (2007). Medications for acute and chronic low back pain: A review of the evidence for an American Pain Society/American College of Physicians clinical practice guideline. Annals of Internal Medicine, 147, 505-514.

Dziadulewicz, E., Brown, M., Dunstan, A., Lee, W., Said, N., \& Garratt, P. (1999). The design of non-peptide human bradykinin $B_{2}$ receptor antagonists employing the benzodiazepine peptidomimetic scaffold. Bioorganic and Medicinal Chemistry Letters, 9(3), 463-468.

Garcia, P., Kolesky, S., \& Jenkins, A. (2010). General anesthetic actions on GABAA receptors. Current Neuropharmacology, 8, 2-9.

Gierthmuhlen, J., Binder, A., \& Baron, R. (2014). Mechanism-based treatment in complex regional pain syndromes. Nature Reviews. Neurology, 10(9), $518-528$.

Higashida, H., Streaty, R., Klee, W., \& Nirenberg, M. (1986). Bradykininactivated transmembrane signals are coupled via No or Ni to production of inositol 1,4,5-trisphosphate, a second messenger in NG108-15 neuroblastoma-glioma hybrid cells. Proceedings of the National Academy of Sciences of the United States of America, 83, 942-946.

Howard, P., Twycross, R., Shuster, J., \& Mihalyo, M. (2014). Benzodiazepines. Journal of Pain and Symptom Management, 47(5), 955-964.

Hugel, H., Ellershaw, J., \& Dickman, A. (2003). Clonazepam as an adjuvant analgesic in patients with cancer-related neuropathic pain. Journal of Pain and Symptom Management, 26, 1073-1074.

Kam, Y., Ro, J., Kim, H., \& Choo, H. (2005). Antagonistic effects of novel non-peptide chlorobenzhydryl piperazine compounds on contractile response to bradykinin in the guinea-pig ileum. European Journal of Pharmacology, 523, 143-150.

Kerstman, E., Ahn, S., Battu, S., Tariq, S., \& Grabois, M. (2013). Neuropathic pain. In: M. Barnes, D. Good, Handbook of clinical neurology. Neurological Rehabilitation. Elsevier B.V., 110, pp. 175-187.

Ludwig, J., \& Baron, R. (2004). Complex regional pain syndrome: An inflammatory pain condition? Drug Discovery Today: Disease Mechanisms, 4(1), 449-455.

Malasics, A., Boda, D., Valisko, M., Henderson, D., \& Gillespie, D. (2010). Simulations of calcium channel block by trivalent cations: $\mathrm{Gd}^{3+}$ competes with permeant ions for the selectivity filter. Biochimica et Biophysica Acta, 1798(11), 2013-2021.

Marcon, R., Claudino, R., Dutra, R., Bento, A., Schmidt, E., Bouzon, Z., Sordi, R., Morais, R., Pesquero, J., \& Calixto, J. (2013). Exacerbation of DSS-induced colitis in mice lacking kinin $B_{1}$ receptors through compensatory up-regulation of kinin $\mathrm{B}_{2}$ receptors: The role of tight junctions and intestinal homeostasis. British Journal of Pharmacology, 168(2), 389-402.

Pesquero, J., \& Bader, M. (1998). Molecular biology of the kallikrein-kinin system: from structure to function. Brazilian Journal of Medical and Biological Research, 31, 1197-1203.

Pleuvry, B. (2008). Mechanism of action of general anaesthetic drugs. Anaesthesia and Intensive Care Medicine, 9(4), 152-153.

Scholz, A. (2002). Mechanisms of (local) anaesthetics on voltage-gated sodium and other ion channels. British Journal of Anaesthesia, 89(1), 52-61.

Stadnicki, A. (2011). Intestinal tissue kallikrein-kinin system in Inflammatory bowel disease. Inflammatory Bowel Diseases, 17(2), 645-654.

Watkins, L., \& Maier, S. (2002). Beyond neurons: Evidence that immune and glial cells contribute to pathological pain states. Physiological Reviews, 82(4), 981-1011. 